\title{
HUGO and HGS clash over 'utility' of gene sequences in US patent law
}

London. The Human Genome Organization (HUGO), has thrown down the gauntlet to those who, it claims, are threatening to undermine the patentability of human genes either by making excessive demands for patent protection of gene sequences or by claiming that all such protection is immoral.

The first target includes groups such as Human Genome Sciences (HGS) in Rockville, Maryland, which is seeking to patent both partial and complete gene sequences, even where their respective biological activity has not yet been identified.

The second threat, according to HUGO officials, is exemplified by the recent decision of the European Parliament to reject attempts by the European Commission to formalize the conditions under which human genes can be patented.

The challenge from HUGO - the international body responsible for coordinating efforts to sequence the complete human genome - comes in a policy statement on the patenting of DNA sequences drawn up by a working party headed by Thomas Caskey, recently appointed head of basic research for the US pharmaceutical company Merck, and president of HUGO.

Behind the statement lies concern that public debates on gene patents are sometimes based on "misinformation concerning the underlying science".

Caskey, for example, says that he was "shocked" by the European Parliament's decision, particularly as it came shortly after a meeting in Paris - attended by a number of members of the parliament - at which "there was a general consensus that there is no serious objection to the patenting of functioning genes".

The HUGO statement, which has been endorsed by the organization's full council, argues that patent protection of human genes is essential to create "necessary incentives for the ongoing development of products without interfering unduly with scientific research".

Even those council members who admit to unease over the idea of patenting human genes say that they acknowledge the Caskey: seeks to need for flexibility. reward creativity.

"Obviously one has to look for a compromise," says John Sulston, director of the UK Medical Research Council's Sanger Centre in Cambridge.

More contentious, at least within the biotechnology industry, is HUGO's firm stand against patenting nucleotide sequences obtained by straightforward sequencing techniques before their biological function has been worked out.

The statement claims that it is the latter work that contains the key intellectual contribution. "The task of identifying biological functions of a gene is by far the most important step in terms of both its difficulty and its social benefit," it says. "It therefore merits the most incentive and protection."

Applying for patent protection on

\section{Curie laid to rest with France's heroes}

Paris. Marie Curie, the codiscoverer of radioactivity, last week became the first woman to be given France's highest honour, burial in the national mausoleum, the Panthéon. The ceremony, broadcast live on national television, was attended among others by outgoing President François Mitterrand, and Lech Walesa, president of Poland, where Curie was born Marya Sklodowska in 1867.

At the ceremony, also attended by two other French Nobel prizewinners, Georges Charpak and Pierre-Gilles de Genne, Mitterrand emphasized the priority given to fundamental research under his presidency. Marie Curie won

\section{IMAGE UNAVAILABLE FOR COPYRIGHT REASONS}

the Nobel prize for physics in 1903 the first woman to do so - for the discovery of natural radioactivity along with her husband Pierre, whose ashes accompanied her to the Panthéon at the request of her relatives. sequences alone - for example on either Expressed Sequence Tags (ESTs), used to identify cDNA clones, or on the cDNAs themselves - without knowing their biological function is "like applying for patents on the table of elements", says Caskey.

But this is sharply disputed by officials at HGS, which has a number of applications on sequences pending with the US Patent Office. Bill Haseltine, the company's chief executive officer, says that he welcomes HUGO's statement as a recognition of "the importance of gene patents to the betterment of human health".

But he remains strongly opposed to attempts to limit patents on partial or full gene sequences whose biological function remains unknown, claiming that even ESTs can have clear usage - for example, to determine whether a gene is being expressed or to locate a restriction enzyme - even if this use is not strictly biological.

At present, says Haseltine, HGS has 70 patents pending on full-length gene sequences of "proposed medical utility". He adds that "a substantial number are biologically active" - acknowledging that for some, no such activity has yet been defined.

In direct conflict with Haseltine's position - and reflecting last year's decision by the US National Institutes of Health not to seek patents on cDNAs - HUGO maintains the granting of such patents could jeopardize its prime objective, namely that the financial rewards should go to those who succeed in identifying functioning genes.

The concern of HUGO officials is that patents granted on partial and uncharacterized cDNA sequences would reward those it describes as making "routine discoveries", while scuttling later patent applications by those who establish the biological function of gene sequences or the application of such knowledge. "Such an outcome would impede the development of diagnostics and therapeutics, which is clearly not in the public interest," says the policy statement.

HGS has been criticized for the conditions which, following a \$125-million deal with Merck's rival SmithKline Beecham, it has placed on access to sequences available in its databanks and those of its Institute for Genomic Research (Nature, 373, 376; 1995).

But Haseltine still disagrees strongly with the thrust of the HUGO statement, which he says misunderstands the patent system. "Patents are about use, and not about knowledge," he says. "I would claim that the patentability of a gene or a gene sequence is dependent on its utility, not on the advancement it makes in biological knowledge related to its function."

David Dickson 